\title{
Know-how to Lead Digital Transformation: the Case of Local Governments
}

\begin{tabular}{|c|c|}
\hline Jeffrey J. Pittaway $^{*}$ & Ali Reza Montazemi * \\
University College London, & McMaster University, \\
School of Management, & DeGroote School of \\
London WC1E 7JE, United & Business, Hamilton, ON L8S \\
Kingdom & 4M4, Canada \\
\hline
\end{tabular}

\begin{abstract}
Local governments are in an ideal position to integrate government, private, and citizen data to deliver beneficial new digitally enabled public services. However, progress towards achieving the benefits has stagnated in many cases. This is because managers lack the requisite know-how to lead the implementation and enactment of integrated enterprise systems to improve the processes of public service delivery, part of a journey called 'digital transformation'. If digital transformations are to progress, we need more nuanced empirical elaboration of the know-how managers require. To that end, this study reports evidence from case studies in 11 local governments in Canada. The findings provide the empirical basis for a theory of the know-how managers require to lead the implementation and enactment of integrated enterprise systems in support of digital transformation. We then propose a new theoretical model of how to transfer that requisite know-how to managers through public-private partnerships, and thereby mitigate barriers to that transfer.
\end{abstract}

\section{Keywords}

Digital transformation; mindful IT governance; technology enactment; knowledge transfer; smart city; public-private partnerships; e-government

\section{Introduction}

New digitally enabled public services can make the everyday lives of citizens easier, more fulfilling, and more secure (Walcroft, Chiasson, \& Murty, 2018). To that end, local governments are using digital technologies to adapt organizational structures and the underlying processes of public service delivery. This approach is part of a journey called 'digital transformation' (Hess, Matt, Benlian, \& Wiesböck, 2016; Luna-Reyes \& Gil-Garcia, 2014; Mahmood, 2016; Mergel, Edelmann, \& Haug, 2019; Schenk \& Dolata, 2020), which is now embedded in the organizational roadmaps of most government bodies (Zaizi, 2018b). Extant research suggests 
that digital transformation has stagnated because city managers lack the requisite know-how to replace legacy system silos with integrated enterprise systems (McKinsey, 2018; Zaizi, 2018a, cf. Gil-Garcia, 2012).

Know-how is the tacit knowledge that enables organizations to coordinate and use resources and capabilities in new ways (Montazemi, Pittaway, Qahri-Saremi, \& Wei, 2012). It can take the form of new vision, expertise, and managerial skills (McKinsey, 2018; Zaizi, 2018a), as well as the knowledge to enact new technology-enabled organizational processes (e.g., Kim, Pan, \& Pan, 2007; Klievink \& Janssen, 2009; cf. Hansen, Kraemmergaard, \& Mathiassen, 2011). Such knowhow is essential for digital transformation in government because: (1) transformation involves a high number of decisions with major implications for the organization that should be informed by interpreting and acting on information from nearly all departments (Elnaghi, Alshawi, \& Missi, 2007; Fountain, 2019; Kohli \& Johnson, 2011; Omar, Weerakkody, \& Millard, 2016); and (2) it is know-how that enables decision makers to accurately interpret and effectively act on that information (Oborn, Barrett, \& Davidson, 2011). Local governments, therefore, cannot plausibly achieve digital transformation without requisite management know-how.

Recognizing the significance of know-how, discussion in digital transformation literature has revolved around how to transfer-in the requisite know-how, such as the relative advantages of different sources (e.g., Hess et al., 2016; Westerman, Bonnet, \& McAfee, 2014). Prior discussion of how to transfer-in the requisite know-how seems premature, however, because there is little systematic empirical analysis of what know-how managers require to lead digital transformation (Hofmann \& Ogonek, 2018; Mergel et al., 2019; Pederson, 2016). In addition, prior surveys eliciting what know-how managers perceive to be important were not theoretically grounded, and are therefore of questionable generalizability (e.g., Hoberg, Krcmar, Oswald, \& Welz, 2015). 
Hence, our focus in this study is a theory-led empirical investigation into the research question:

\section{"What know-how do local government managers require to lead digital} transformation?"

In order to address our research question, this article offers a theoretical perspective on the know-how to manage the disruptive 'punctuated' organizational changes in government (Iannacci, Seepma, de Blok, \& Resca, 2019; Jones \& Baumgartner, 2012); specifically the knowhow managers require to lead the implementation and enactment of integrated enterprise systems in support of digital transformation (Vial, 2019; Westerman et al., 2014; Zaizi, 2018b). We assess our theoretical perspective in the empirical context of local governments because they are in an ideal position to integrate government, private (e.g., industrial, utility, corporate, community) and citizen data to generate the greatest mutual benefits (Sá, Rocha, \& Cota, 2016; Walcroft et al., 2018).

Our findings provide the empirical basis for a model and theory of the know-how managers require to lead digital transformation. The study thus begins to address the lack of systematic empirical evidence to date of what know-how local government managers require to lead digital transformation (Hofmann \& Ogonek, 2018; Mergel et al., 2019; Pederson, 2016; Sá et al., 2016). It also contributes to the nascent body of generalizable theory in the public administration context (Bannister \& Connolly, 2015) by building on punctuated equilibrium theory, which affords middle-range explanations of digitally enabled change that can be generalized both analytically and empirically (Lyytinen \& Newman, 2008). In addition, with the findings in hand, we propose a second model and six recommendations on how to transfer the requisite know-how through public-private partnerships. This research, therefore, contributes to our understanding of barriers that prevent knowledge transfer, and proposes theoretical solutions, which could be 
critical for practitioners to deliver the promise of government transformation with digital technologies (Gil-Garcia, Chengalur-Smith, \& Duchessi, 2007; Gil-Garcia, Zhang, \& Puron-Cid, 2016; Pardo, Cresswell, Thompson, \& Zhang, 2006; Schenk \& Dolata, 2020).

\section{Digital Transformation in Local governments}

Organizations that fully achieve digital transformation tend to realize significantly higher levels of productivity and efficiency than their peers (Westerman et al., 2014). To achieve such benefits, organizations enact an integrated enterprise system in support of a coordinated approach to service delivery and a unified view of improved organizational processes (Kohli \& Johnson, 2011; Matt, Hess, \& Benlian, 2015; Westerman et al., 2014; Zaizi, 2018b). In the course of digital transformation, core organizational processes are redesigned, new technology tools replace old ones, new skills are developed, and new ways of working are introduced. Leading digital transformation involves making important, sometimes disruptive or 'punctuated' organizational changes from legacy ways of operating (Iannacci et al., 2019; Jones \& Baumgartner, 2012; Sabherwal, Hirschheim, \& Goles, 2001). Doing so requires the organization to challenge its own assumptions about ways of operating (Fitzgerald, Kruschwitz, Bonnet, \& Welch, 2013). And unlike incremental change, which can be achieved by a few individuals, digital transformation can only be achieved by actively engaging managers and employees in making new ways of operating a reality (Westerman et al., 2014). Government bodies are pursuing a similar digital transformation journey to achieve high levels of cooperation among stakeholders to improve the efficiency and quality of public service delivery (Chourabi, Nam, Walker et al., 2012; Klievink \& Janssen, 2009; Kohli \& Johnson, 2011; Matt et al., 2015). Government bodies can enable digital transformation by enacting an integrated enterprise system in support of high levels of cooperation among stakeholders with process management (Cordella 
\& Iannacci, 2010; Weerakkody, Omar, El-Haddadeh, \& Al-Busaidy, 2016). Alternatively, governments can implement new technologies without enacting an integrated enterprise system for process management in an effort to avoid the costs of process change. However, the latter approach leads to problems such as: (1) inefficiencies and errors due to redundant search and reentry of data in multiple incompatible systems; (2) lack of understanding among stakeholders regarding their role in organizational processes that span multiple departments; and (3) difficulty attaining consensus on priorities because of lack of collaboration and transparency among stakeholders (Nath, 2012; Weerakkody et al., 2016). Therefore, if managers are to lead digital transformation and realize the full benefits for the organization, enacting an integrated enterprise system is a prerequisite. However, as few as $10 \%$ of local governments have actually taken that step (Manville, Cochrane, Cave et al., 2014). The question of what know-how do local government managers require to lead digital transformation therefore arises.

We believe, as others do, that the requisite know-how pertains broadly to managing organizational change (e.g., Fountain, 2019; Luna-Reyes \& Gil-Garcia, 2014; Schenk \& Dolata, 2020). Private sector studies have long noted that organizational performance relates to aligning IT with organizational strategy, IT with organizational structures, and structure with strategy (Hirschheim \& Sabherwal, 2001). A rich body of organizational dynamics literature examines how private organizations manage change in these dimensions over time. By comparison, Mergel et al. (2019) and Kitchin (2015) argue that guidance for managing dynamic organizational change is generally under-developed and lacking in nuance and/or empirical evidence in the government context. A review by Hofmann and Ogonek (2018) also finds there is little comprehensive empirical analysis of the know-how local government managers require. To contribute deeper insight to the literature, we adopted an established organizational dynamics 
theory - punctuated equilibrium - as a conceptual lens to examine empirically what know-how enables some local government managers to lead digital transformation, and what know-how is lacking where digital transformation stagnated.

\section{A Punctuated Equilibrium perspective on Digital Transformation}

Drawing on punctuated equilibrium theory, Sabherwal et al. (2001) developed a theory of IT alignment patterns that makes it possible to assess the organizational dynamics of digital transformation over time. By selecting punctuated equilibrium theory, our study complements prior studies of change over time in government bodies that are based on stage of life cycle models (for reviews see Iannacci et al., 2019; Niehaves, Plattfaut, \& Becker, 2013). Punctuated equilibrium theory allows for deeper analysis of the dynamic ways in which digital transformation can progress or regress iteratively in different organizational dimensions at different paces over time in government (Jones \& Baumgartner, 2012). Such a pattern of change does not necessarily reflect the linear, sequential, deterministic or invariant set of states that tend to be assumed in e-government stage of life cycle models (Brown, 2007; Iannacci et al., 2019). Hence, we believe as others do (Jones \& Baumgartner, 2012; Silva \& Hirschheim, 2007) that punctuated equilibrium theory is well suited to deeper analysis of dynamic iterative transformation over time in the public sector.

Central to punctuated equilibrium theory is the notion that radical changes in an organization's services and technology require modifications in the underlying dimensions of its 'deep structure' (Silva \& Hirschheim, 2007). In the context of digitally enabled change, organizational deep structure can be defined as the organization's choices in four dimensions: (1) organizational strategy; (2) IT strategy; (3) organizational structure; and (4) IT structure (Sabherwal et al., 2001). By accumulating a history of experience while embedded in an organization's deep 
structure, managers establish cognitive frameworks, which are a set of givens about the organization's situation and how it will behave (Gersick, 1991). Cognitive frameworks form a stable foundation from which managers operate, thus providing managers with a sense of competence in how to achieve the incumbent organizational strategy. Their established cognitive frameworks can be profoundly functional when organizational strategy remains stable.

Managers' established cognitive frameworks can become dysfunctional, however, when organizations adopt an innovative new IT enabled organizational strategy. In this scenario, executing the new organizational strategy depends on attaining the appropriate new IT strategy, organizational structure, and IT structure (Hirschheim \& Sabherwal, 2001). However, managers tend to interpret the need for novel changes within the limits of their old cognitive frameworks, thereby preserving their old cognitive frameworks (Gersick, 1991). Consequently, managers tend not to change their fundamental approach to organizational processes, strategies and structures. Instead, managers tend to preserve deep structure. If organizations are to attain the appropriate IT strategy, organizational structure, and IT structure to execute an innovative new IT enabled organizational strategy, they must break managers' old cognitive frameworks in order to make way for new ones. This break from the past is essential to digital transformation (Chanias, Myers, \& Hess, 2019), and best practices for managing this frame-breaking change call for a revolutionary period of discontinuous change (Tushman, Newman, \& Romanelli, 1986). Discontinuous change is frame-breaking change. During revolutionary periods of discontinuous change, leaders rapidly modify all four dimensions of deep structure concurrently. Managing concurrent change in strategy and structure, such as a fresh mission with revised norms and values (i.e., strategy) backed up with power and status (i.e., structure), provides strong reinforcement of transformation. Short-term detrimental effects on organizational performance, 
which stem from the disruption of organizational attributes during concurrent change, stress the need to complete these changes rapidly.

To achieve rapid concurrent organizational change, managers should exploit political changes, visionary new leadership, public demand for services, new technologies, and crises induced by poor performance and looming deadlines as opportunities to trigger rapid and concurrent change (Silva \& Hirschheim, 2007). Top management should exploit such trigger events to usher in a new cognitive framework by championing a new vision for the organization's future that raises aspirations, by generating enthusiasm for a new approach to achieve the vision, and by highlighting the gaps between existing organizational arrangements and those necessary to achieve the new vision. For example, empirical research by Moon and Norris (2005) shows that digital transformation progress in local government is determined, in part, by adopting an organizational strategy with an innovation orientation. Pursuing an innovation strategy implies a radical shift from the traditional government strategy of using IT to cut the cost of existing operations (Omar et al., 2016; Weerakkody, Irani, Lee, Osman, \& Hindi, 2015). Such a radical shift necessitates a commensurate change in organizational structure, IT strategy, and IT structure (Silva \& Hirschheim, 2007). Integrated enterprise systems implementation is expected to bring about tightly coupled task interdependence, as it will have to run across different departments (i.e., organizational structure). This implies a profound transformation of the targeted organizational processes as well as a redistribution of resources (Sharma \& Yetton, 2007). To this end, all functional and process strategies are encompassed under the umbrella of IT strategy with digital resources serving as the connective tissue. IT strategy is realized through the supporting IT structure dimension.

The IT structure dimension refers to the structure of decision rights and accountability for IT 
management decisions (Sabherwal et al., 2001), which has come to define the structure of IT governance (Montazemi, Pittaway, \& Qahri-Saremi, 2010; Pittaway \& Montazemi, 2018; Xue, Liang, \& Boulton, 2008). Best practices call for a mindful approach to IT governance involving five practices: deference to expertise, commitment to resilience, performance monitoring, sensitivity to operations, and complexity seeking (Plotnick, Turoff, \& Van Den Eede, 2009; Weick, Sutcliffe, \& Obstfeld, 1999). Deference to expertise places individuals with the most relevant knowledge in direct control of key decisions. Because chief information officers (CIOs) should possess a unique mixture of IT and organizational knowledge, they should be empowered to identify and interpret the potential of integrated enterprise systems to the organization (Guillemette \& Paré, 2012). Commitment to resilience requires managers to expect errors, and to develop techniques that enable a quick recovery while errors are still small and manageable (Plotnick et al., 2009; Weick et al., 1999). To do so, all experts must be on-board and actively collaborating in strategic IT decisions. The city of Chicago, for example, found that enacting integrated enterprise systems required mayors to lead task forces and to issue policy calling for managers to leverage technology to drive innovation wherever possible (Mathis, 2014). Closely monitoring performance highlights gaps between existing organizational arrangements, and those necessary to achieve new strategic objectives (Plotnick et al., 2009; Weick et al., 1999). Sensitivity to operations helps to mitigate managers' oversimplified interpretations of the need for change. It is a collective accomplishment that requires knowing how to promulgate a shared vision for the organization's possible future states. Complexity seeking involves cycles of renewing and revising organizational processes, such that they encapsulate new experiencebased know-how over time. In this way, processes that underly public services become increasingly complex, which increases the repertoire of possible responses to trigger events 
(Janowski, 2015). Based on the preceding literature, we can conceptualize enacting an integrated enterprise system - as part of digital transformation - in terms of managing discontinuous change in all four dimensions of deep structures from one time period to another, as depicted in Figure 1.

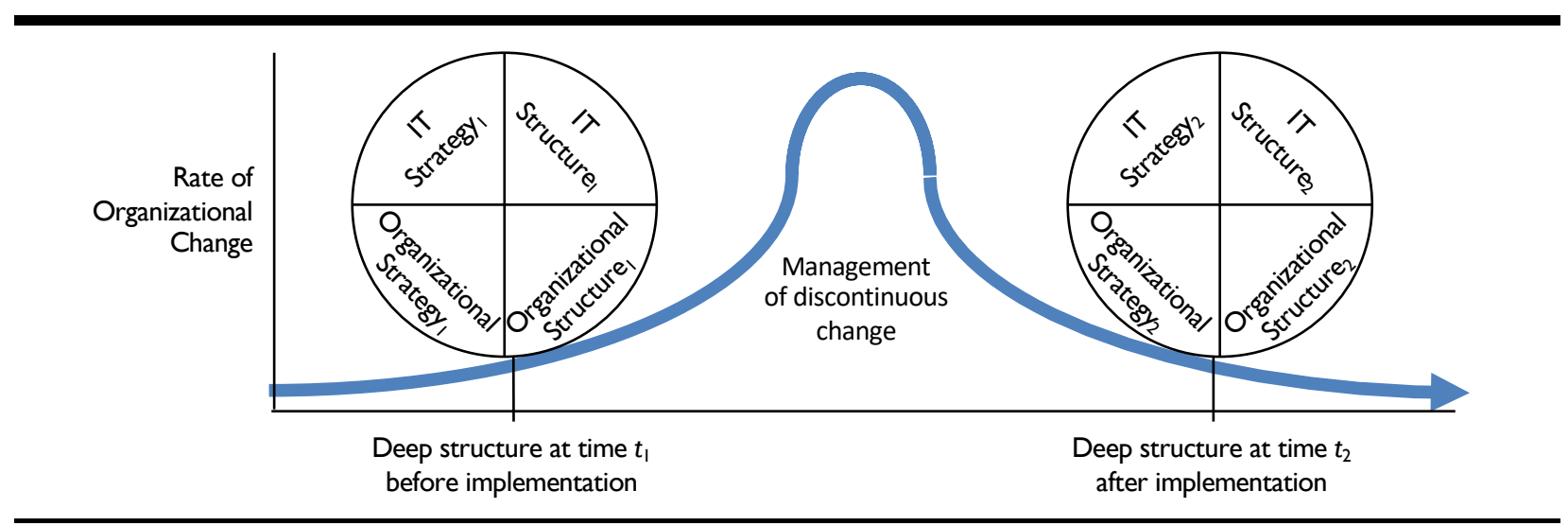

Fig. 1. Conceptual model: enacting an integrated enterprise system as part of digital transformation

Substantial risks arise when, despite the need for significant change in response to trigger events, top managers avoid initiating significant changes to strategy and structure. In these situations, managers adhere to the old strategies and structures (McDonald \& Westphal, 2003), and pursue convergent change (Tushman et al., 1986). During convergent change, managers can implement new IT systems that change horizontal integration of organizational processes (i.e., organizational structure), but they attempt piecemeal changes in support of old organizational strategy. Considering that even piecemeal changes imply shifts in the balance of power and status, some managers would lose in the change while others gain. Consequently, this piecemeal approach to change becomes bogged down in politics, as pockets of resistance are provided a chance to grow, develop, and undermine change. Organizations risk emerging from such convergent change weakened by discord, without accomplishing necessary changes in deep structure (Gersick, 1991). We should therefore expect that local governments fail to enact 
enterprise systems as an integrated system in support of digital transformation because managers lack the know-how to exploit trigger events and manage discontinuous change in all four dimensions of deep structure. We empirically assessed our theory-based conjecture as follows.

\section{Research Design}

In order to empirically assess what know-how do local government managers require to lead digital transformation, we selected 11 established Canadian local governments for comparative case studies for three reasons. First, Canada was consistently ranked among the top 10 in egovernment initiatives in United Nations reports for 2001-2010, and we would thus expect managers' know-how for digital transformation to be well-represented in Canadian local governments. Second, the 11 local governments selected for our empirical research had acquired enterprise systems 13 years ago. This enabled us to assess their comparative digital transformation progress over time. Third, enterprise systems should be well-integrated within 11 years (Phang, Kankanhalli, \& Ang, 2008). Nonetheless, a report (MAH, 2010) showed that, within that time period, the 11 local governments were at different stages of enterprise systems integration, and they thus provide a rich variation of local government managers' know-how to inform our research.

To assess our research question, we examined the discursive and material realities of CIOs' digital transformation experiences illuminated through comparative studies that contrast the experiences of different local governments (Kitchin, 2015). The approach contributes substantive insight into how specific initiatives are formulated, how they gain (or fail to gain) political and financial backing, and how they roll out in the messy reality of established local governments. To that end, and consistent with prior case studies in local governments (Kamal, Weerakkody, \& Irani, 2011), our research methodology consisted of three phases: (1) research design; (2) data 
collection; and (3) data analysis and synthesis. The phases are illustrated in Figure 2 and highlighted as follows.

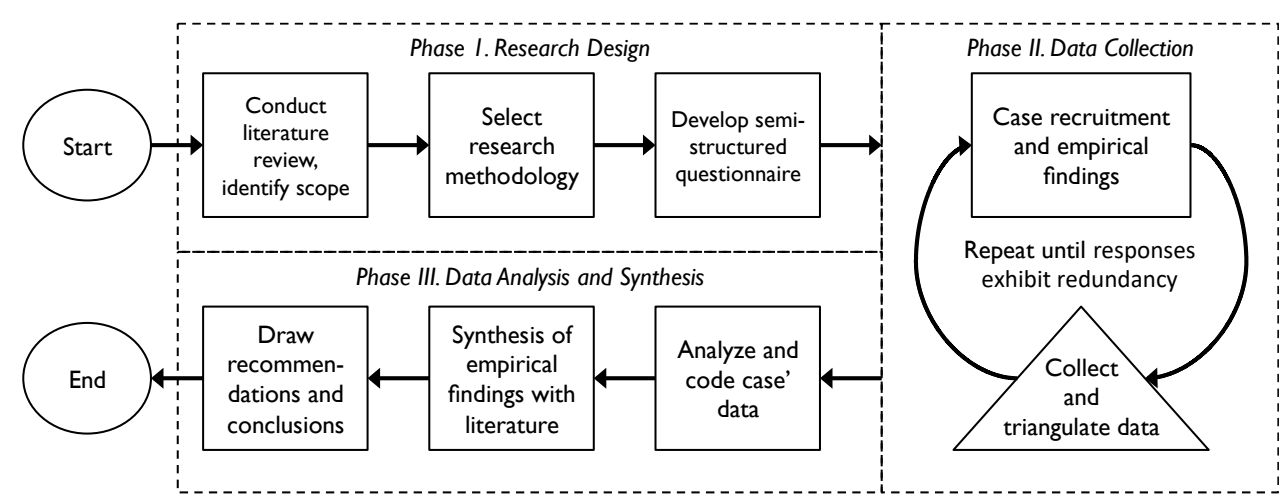

Fig. 2. Adopted research design for this study

The preferred research design was based on an exploratory case studies methodology (Yin, 2003) because extant theory is generally under-developed and lacking in nuance and/or empirical evidence in our context (Gil-Garcia et al., 2016; Hofmann \& Ogonek, 2018; Kitchin, 2015; Mergel et al., 2019). Our case studies concerned 11 local governments' implementations and enactments of integrated enterprise systems. This type of case study can also be labeled as revelatory (Yin, 2003) since researchers have the opportunity to investigate situations and phenomena of which little is known. Through semi-structured interviews with CIOs in each of the local governments, we gained access to the experiences of these executives. As top managers, CIOs possess the know-how to participate in making digitization choices and to orchestrate technology, people, operational processes and policies in support of digital transformation (Kohli \& Johnson, 2011). The CIO interviews presented us the opportunity to explore how local governments managed change in deep structure. The responses resulted in 19 hours of transcripts, which we used to code key events, interpretations and organization-level factors. The semi-structured questions and coding matrix are incorporated into Table 1 in the next section. 
We took steps to naturally control political, service, and technology triggers for government bodies (Silva \& Hirschheim, 2007) by selecting 11 local governments in a single jurisdiction that: (1) experienced the same regulatory changes and four-year election cycles; (2) ultimately delivered the same 12 basic public services; and (3) had all acquired enterprise systems technology in the same year. Digital transformation progress is a function of implementing integrated enterprise systems and user's enactment of integrated systems rather than nonintegrated or silo alternatives. We therefore triangulated transformation progress with three measures: (1) selection by the CIOs of the representative IT architectures (one fully integrated and three that were not, cf. Ross, 2003); (2) budget documents indicating whether the majority of annual IT budgets for new projects were directed to fully integrated enterprise systems usage or to alternatives (Ross, 2003); and (3) whether or not users received Gartner industry-benchmark investments (Guevara, Stegman, \& Hall, 2012) in training about how to use (i.e., enact) enterprise systems in support of integrated organizational processes (e.g., Azad \& Faraj, 2008). Organizational strategy was coded in terms of the established typology of 'defenders' (pursuing efficiency in existing operations), 'prospectors' (exploring for innovative opportunities), or 'analyzers' (a hybrid of both types) (Sabherwal et al., 2001). IT strategy was coded in terms of the established typology of low-cost ('efficiency'), differentiation, innovation, growth, or alliances (ibid.). Organizational structure was coded in terms of vertical and horizontal integration arrangements (Silva \& Hirschheim, 2007). Further data triangulation involved comparing and contrasting the interview findings with document reviews (Kamal et al., 2011). To assess IT structure, IT governance structure data were gathered from each CIO on a COBIT matrix indicating which managers had accountability for 15 archetype IT governance decisions (ITGIOGC, 2005). Deviations from COBIT best practices enabled us to code whether or not an 
organization followed five best practices for mindful IT governance as follows: (1) deference to expertise (i.e., did senior and department managers share accountability with the CIO in strategic IT decisions); (2) commitment to resilience (i.e., did department managers and auditors share accountability with the $\mathrm{CIO}$ in risk, integrity and availability management); (3) performance monitoring (i.e., were all senior and department managers accountable with the CIO in monitoring performance); (4) sensitivity to operations (i.e., were all senior and department managers accountable with the $\mathrm{CIO}$ in promulgating an innovation strategy); and (5) complexity seeking (i.e., were all senior and department managers accountable with the CIO in seeking change in resources use and processes). Appendix A contains further rationale for the research design. Next, we present our comparative analysis.

\section{Comparative Analysis}

The analysis of digital transformation over time necessitates a comparison of progress in different time periods. The logical initial time period for comparison should coincide with the initial change trigger, and because new technology is one such example (Gersick, 1991), our comparison begins in $t_{1}$ when all 11 local governments acquired enterprise systems.

\subsection{Pre-implementation $t_{1}$}

The CIOs we interviewed noted that their organizations took advantage of subsidies offered by higher-tier government at $t_{1}$ to acquire their first enterprise systems with the intention of replacing the existing incompatible department-based legacy systems - i.e., an 'application silos' IT architecture. Empirical research at $t_{1}$ (Kumar, Maheshwari, \& Kumar, 2002) also shows that in Canadian local governments: (1) organizational strategy was focused on lowering operating costs (i.e., defender type); (2) organizational structure was based on traditional departmental structures, which were not horizontally integrated (i.e., vertical type); (3) IT strategy was focused 
on lowering operating costs (i.e., efficiency type); and (4) their IT structures deviated from recommended best practices as follows. Kumar et al. (2002) found that, at $t_{1}$ : (1) IT acquisition decisions were often made by managers with minimal CIO involvement (i.e., did not defer to expertise of CIO; poor collaboration for commitment to resilience); (2) the local governments had largely avoided re-engineering old processes (i.e., poor sensitivity to operations; failure to seek complexity by renewing old processes); and (3) network or system failures often resulted in standstills in the organizations (i.e., did not monitor performance of IT enabled processes for potential failures before failures occurred). In sum, the 11 local governments were conceptually similar at $t_{1}$ with respect to the four dimensions of deep structure in which we were interested. Next, we compared the findings from $t_{1}$ with findings from $t_{2}$.

\subsection{Implementation and Enactment $t_{2}$}

Selecting $t_{2}, 13$ years after $t_{1}$, as the comparison period allowed the local governments more than the standard 11 years to complete their enterprise systems integrations (Phang et al., 2008). We used pseudonyms (e.g., Alpha, Beta, Theta) to anonymize the participants as requested. As detailed in Appendix B, our cluster analysis of annual IT spending per employee at $t_{2}$ (a proxy for user training on enterprise systems) found three significantly distinct clusters: (1) a cluster containing a single local government (Alpha); (2) a cluster of three local governments (Iota, Gamma, Delta); and (3) a cluster of seven local governments (Mu, Lambda, Epsilon, Beta, Zeta, Theta, Kappa). In order to assess enactment of integrated enterprise systems, the clusters were triangulated with data on the degree to which IT project funding was directed to integrated use of enterprise systems, or to alternatives. The Alpha CIO confirmed that "our portfolio management group makes sure all IT projects are in compliance with the integrated enterprise architecture.” Enactment in the cluster of three local governments was exemplified by the Gamma CIO: "For 
things like purchasing, everyone's using the same integrated enterprise system, but we're still trying to get coordination around information management across departments." Enactment in the cluster of seven local governments was exemplified by the Beta CIO: "People use specialized application silos to support their departments, and it causes a lot of problems; so, we need to bring them to some sort of integrated structure that benefits everyone." Hence, the triangulated findings established three clusters for comparative analysis. Coding for all empirical data at $t_{2}$ are summarized in Table 1 by cluster for the purpose of comparative analysis. Tables C1, C2 and C3 in Appendix C provide clustered CIO responses to the COBIT IT governance matrix, which we used to code mindful IT governance (i.e., IT Structure) in Table 1. Findings from comparative analyses are elaborated next.

Table 1

Comparison of enterprise systems integration and digital transformation over time

\begin{tabular}{|c|c|c|c|c|c|c|c|}
\hline \multirow[t]{3}{*}{ Concepts } & \multirow[t]{3}{*}{ Dimensions } & \multirow{3}{*}{$\begin{array}{l}\text { Semi-structured questions } \\
\text { To what extent does your local government } \\
\text { practice/have... }\end{array}$} & \multirow[t]{3}{*}{ Supporting Literature } & \multirow[t]{3}{*}{\begin{tabular}{|l|} 
Data \\
Sources
\end{tabular}} & \multicolumn{3}{|c|}{$\begin{array}{l}\text { Findings for local } \\
\text { governments in... }\end{array}$} \\
\hline & & & & & \multirow[t]{2}{*}{$t_{1}$} & \multicolumn{2}{|c|}{$\begin{array}{l}t_{2} \\
\text { Clusters }\end{array}$} \\
\hline & & & & & & 7 & 31 \\
\hline \multirow{3}{*}{$\begin{array}{l}\text { Integrated } \\
\text { enterprise } \\
\text { systems } \\
\text { implemen- } \\
\text { tation }\end{array}$} & D IT architecture & $\begin{array}{l}\text {...achieved their desired "integrated } \\
\text { architecture" profile? }\end{array}$ & $\begin{array}{l}\text { Ross, 2003; } \\
\text { Weerakkody, Janssen, \& } \\
\text { Dwivedi, 2011) }\end{array}$ & I,D & $x$ & $x$ & $\begin{array}{ll} & \checkmark\end{array}$ \\
\hline & \multirow{2}{*}{$\begin{array}{l}\text { Enactment of } \\
\text { integrated } \\
\text { enterprise } \\
\text { systems }\end{array}$} & $\begin{array}{l}\text {... majority of IT funding to business cases for } \\
\text { integrated, not silo usage of enterprise systems? }\end{array}$ & (Ross, 2003) & I,D & $x$ & $x$ & $\times \checkmark$ \\
\hline & & $\begin{array}{l}\text {...benchmark-level investments in user } \\
\text { education to enact integrated enterprise } \\
\text { systems? }\end{array}$ & $\begin{array}{l}\text { (Azad \& Faraj, 2008; } \\
\text { Devadoss, Pan, \& Huang, } \\
\text { 2002; Guevara et al., } \\
\text { 2012; Orlikowski, 2000) }\end{array}$ & $\mathrm{I}, \mathrm{D}$ & $x$ & $x$ & $\times \sqrt{ }$ \\
\hline \multirow[t]{2}{*}{$\begin{array}{l}\text { Trigger } \\
\text { events }\end{array}$} & External & $\begin{array}{l}\text {...4-year election cycles? } \\
\text {...experienced regulatory changes? } \\
\text {..12 basic public services? } \\
\text {...integrated enterprise systems technology } \\
\text { acquired in } 1999 ?\end{array}$ & $\begin{array}{l}\text { (Hanna, 2010; MAH, } \\
\text { 2010; Silva \& } \\
\text { Hirschheim, 2007) }\end{array}$ & \begin{tabular}{|l}
$D$ \\
$D$ \\
$D$ \\
$I, D$
\end{tabular} & & $\begin{array}{l}\sqrt{ } \\
\sqrt{ } \\
\sqrt{ } \\
\sqrt{ }\end{array}$ & $\begin{array}{ll}\sqrt{ } & \sqrt{ } \\
\sqrt{ } & \checkmark \\
\sqrt{ } & \sqrt{ } \\
\sqrt{ } & \sqrt{ }\end{array}$ \\
\hline & - Internal & $\begin{array}{l}\text {...experienced performance crisis? } \\
\text {...visionary new leadership? }\end{array}$ & $\begin{array}{l}\text { (MAH, 2010; Silva \& } \\
\text { Hirschheim, 2007) }\end{array}$ & I,D & & $\begin{array}{l}x \\
x\end{array}$ & $\begin{array}{l}\times \\
\times\end{array}$ \\
\hline \multirow{4}{*}{$\begin{array}{l}\text { Best practices } \\
\text { for managing } \\
\text { discontinuous } \\
\text { change }\end{array}$} & $\begin{array}{l}\text { Organizational } \\
\text { Strategy }\end{array}$ & $\begin{array}{l}\text {... analyzer/prospector organizational } \\
\text { strategy? }\end{array}$ & $\begin{array}{l}\text { (Sabherwal et al., 2001; } \\
\text { Tushman et al., 1986) }\end{array}$ & I,D & $x$ & $x$ & $x$ \\
\hline & - IT Strategy & ...innovator type IT strategy? & $\begin{array}{l}\text { (Sabherwal et al., 2001; } \\
\text { Tushman et al., 1986) }\end{array}$ & I,D & $x$ & $x$ & $x$ \\
\hline & $\begin{array}{l}\text { Organizational } \\
\text { Structure }\end{array}$ & ...vertical+horizontal process integration? & $\begin{array}{l}\text { (Sabherwal et al., 2001; } \\
\text { Tushman et al., 1986) }\end{array}$ & I,D & $x$ & $x$ & $\checkmark$ \\
\hline & $\begin{array}{l}\text { IT Structure } \\
\text { (mindful IT } \\
\text { governance) }\end{array}$ & $\begin{array}{l}\text {...deference to CIO expertise? } \\
\text {...collaborative executive decision- } \\
\text { making (commitment to resilience)? } \\
\text {...new performance monitoring? } \\
\text {... shared vision (sensitivity to operations)? } \\
\text {...change (complexity) seeking? }\end{array}$ & $\begin{array}{l}\text { (Plotnick et al., 2009; } \\
\text { Tushman et al., 1986; } \\
\text { Weick et al., 1999) }\end{array}$ & $\begin{array}{l}\text { I,D } \\
\text { I,D } \\
\text { I,D } \\
\text { I,D } \\
\text { I,D }\end{array}$ & $\begin{array}{l}\times \\
\times \\
\times \\
\times \\
\times\end{array}$ & $\begin{array}{l}x \\
x \\
x \\
x \\
x\end{array}$ & $\begin{array}{ll}\checkmark & \checkmark \\
\checkmark & \checkmark \\
\times & \checkmark \\
\times & \checkmark \\
\times & \checkmark\end{array}$ \\
\hline
\end{tabular}

Notes: Data sources $(\mathrm{D}=$ documents, $\mathrm{I}=$ interviews $)$; Findings $(\boldsymbol{}=$ =attribute present; $\mathrm{X}=$ attribute not present $)$ 
Further triangulating evidence from department budgets showed that Alpha made systematic department-level investments in educating its employees about the new integrated organizational processes and how to use technology to achieve this level of technology enactment. For instance, the fire services department at Alpha explicitly identified education as a budgeted component in the rollout of new IT enabled organizational processes. Alpha explicitly recognized education as necessary to help its employees understand how to use IT to improve the cost and quality of fire services. Alpha's emphasis on user education to enact integrated enterprise systems was reflected in per-employee investments that were consistent with mean private-sector benchmarks (Guevara et al., 2012) (mean difference $=-0.0098$, not significant) and significantly higher than the other ten local governments $(\mathrm{F}=759.813, \mathrm{p}<0.001)$. Further triangulating these findings, $\mathrm{CIO}$ responses showed that, in $t_{2}$, only Alpha was directing the majority of funding to IT projects that explicitly utilized the integrated enterprise systems rather than projects that would use silo alternatives. Alpha's CIO explained that enacting an integrated enterprise system was key to the organization's timely and efficient innovation of a single-point contact center for all public services, and to winning an international award as one of the world's best 'smart city' governments. The $\mathrm{CIO}$ also stated that the IT architecture provided an integrated enterprise system of standardized organizational processes across the boundaries of public service delivery. Alpha had transformed as intended by enacting digital technologies to adapt organizational structures and the underlying processes of service delivery (Westerman et al., 2014).

The cluster of three local governments also exhibited integrated technology implementations but did not make benchmark-level investments in user education to achieve the same level of integrated enterprise systems enactment as Alpha. As exemplified by the Gamma CIO, "Whenever we talk about integrated initiatives the reaction is 'well I'm fine, Jack', so the 
enterprise system is really separated between the operating departments." Consequently, users at all three local governments were not enacting fully integrated enterprise system to support high levels of cooperation among stakeholders with process management. In addition, none of the cluster of seven local governments made sufficient benchmark-level investments in user education to achieve Alpha's level of integrated enterprise systems enactment. Instead, the local governments enacted isolated modules of enterprise systems alongside legacy systems and workarounds as application silos to support incompatible departmental processes. As a result, the 10 local governments (the clusters of three and seven) had not digitally 'transformed' in the way Alpha had.

Alpha experienced the external trigger events of four-year election cycles, rising demand for public services, and acquiring enterprise systems technology. However, these external trigger events alone cannot explain the differences between digital transformation progress at Alpha versus the other 10 local governments; all 11 local governments experienced the same three external triggers. Instead, we found Alpha's distinguishing factor was its top management knowhow. This know-how enabled Alpha's top managers to exploit internal trigger events of crisis and visionary newcomers as opportunities to break managers' old cognitive frameworks, as follows.

\section{Discussion}

\subsection{What know-how do local government managers require to lead digital transformation?}

To address public issues and achieve a multi-stakeholder, municipally-based partnership, Alpha's top managers initiated frame-breaking change by exploiting a political crisis that called into question the established controls for IT investments. They exploited this trigger event to lead discontinuous change. The CIO explained, "The mayor wanted our website to become the best in 
the world, to compete with other cities, so we developed the vision of an enabled city with local government anytime, anywhere." They also hired a new CIO with visionary ideas from outside the organization. As a result, Alpha adopted a new 'analyzer' type organizational strategy (i.e., a hybrid of innovation and efficiency), together with a new 'innovation’ type IT strategy.

To execute the new organizational strategy, top management at Alpha knew how to use enterprise systems integration to change organizational structure by adopting the horizontally and vertically integrated best-practiced organizational processes embedded in enterprise systems. As the CIO explained, "We did a complete business process re-engineering of the services in all programs so users could take maximum advantage of the central enterprise system and feed information into it."

The IT enabled change in Alpha's organizational structure was supported with a new IT structure. The new structure shifted the balance of IT investment power and status away from department managers to the CIO and an IT group led by top management, who directed IT investments toward integrated enterprise systems. Given the new CIO's high power and status, senior and department managers fully engaged with (i.e., deferred to expertise of) the CIO to identify and interpret how the integrated enterprise systems would bring strategic benefits to the organization (See Table C1 section (a), e.g., "Our IT strategic groups are led by executive management; so we [IT group] are really starting to connect with those business players, who now understand the IT and business opportunities for the next two to three years, which helped us to get a strategic view of IT"). In addition, department managers and auditors shared accountability in risk, integrity and availability management with the CIO (See Table C1, sections (a) and (c)). As expected, the shift in power raised resistance from department managers at first. However, Alpha senior and department managers knew how to counteract resistance by 
closely monitoring performance, and using evidence of substandard operational performance to highlight gaps between existing organizational arrangements, and those necessary to support high levels of cooperation among stakeholders (See Table C1, section (d), e.g., "At a strategic level we ask what are we getting out of this investment in IT, how does it align with the strategic objectives of the mayor, council, public?", Alpha CIO).

Once managers' old cognitive frameworks were disconfirmed, top management knew how to promulgate a new shared vision among departments to innovate the organizational processes of public service delivery (i.e., sensitivity to operations) (See Table C1, Strategy communicated). To innovate, Alpha adopted the integrated best-practiced organizational processes embedded in enterprise systems (i.e., complexity seeking) (See Table C1, Productive integrated use). In sum, the know-how to exploit internal trigger events and manage discontinuous change in all four dimensions of deep structure enabled Alpha to enact enterprise systems as an integrated system to support high levels of cooperation among stakeholders with process management.

\subsection{What gaps in local government managers' know-how lead to stagnated digital transformations?}

As previously discussed, the cluster of three local governments were partially enacting integrated enterprise systems while the cluster of seven local governments were enacting enterprise system modules in application silos (i.e., islands of automation). Digital transformation progress had therefore stagnated at all 10 local governments and fell short of Alpha's achievements. The stagnated transformations were problematic because, like Alpha, all 10 local governments had experienced external trigger events - four-year election cycles, rising demand for 12 core public services, and acquisition of enterprise systems technology - that signaled the need for innovation in public service delivery. Unlike at Alpha however, top management at the 10 local governments did not exploit internal triggers of performance crisis and visionary new leadership 
as opportunities to initiate discontinuous change in deep structure. Instead, managers in all 10 cases pursued convergent change that kept some or all dimensions of deep structure largely unchanged, which, as detailed below, failed to break managers' old cognitive frameworks.

Consistent with convergent change, CIOs at all 10 local governments justified enterprise systems enactment in terms of the old organizational strategy, and not in terms of an opportunity for radical change in deep structure. Their approach to IT strategy also remained unchanged. They adhered to the old low-cost strategy, rather than adopt a strategy of innovation (e.g., "IT is still viewed as a cost center; I want to shift this, but my problem is how do you change IT from a cost center to an opportunity center?" Beta CIO). The cluster of seven local governments exhibited no change from an organizational structure of vertical departmental silos, whereas the cluster of three exhibited some (but incomplete) horizontal integration of organizational processes. None of the 10 local governments adopted the mindful best practices for IT governance (i.e., stagnant IT structure). In the cluster of seven local governments, top management did not defer to the expertise of the CIO in IT acquisition decisions (See Table C3 section (a)). The Mu CIO described the situation as, "When you look at who participates in the IT strategic team, we do not have senior managers." Senior management was not alongside the CIO as part of mindful IT governance. In the cluster of seven local governments, departments had their own 'shadow' (unofficial) IT budgets and dictated technology choices to the IT group. This approach marginalized CIO involvement. Rather than exercising joint accountability, departments held the IT group accountable for the risk, integrity and availability of the technology. The Mu CIO described the experience as, "Typically department managers have acquired a system and then they don't want to sustain it so they come over to the IT group and say 'you sustain it'”, which reflects a less mindful commitment to resilience (See Table C3, IT Risk, Integrity, Availability). 
In the cluster of three local governments, top management learned to defer to the expertise of the CIO in IT acquisition decisions and collaborate on strategic IT decisions (See Table C3 section (a), e.g., "Council authorized the IT group to be the custodian and the guardian of the technology vision of the organization", Gamma CIO). This enabled local governments in the cluster of three to achieve an integrated IT architecture, whereas the cluster of seven local governments did not (See Table C3 section (a)).

Department managers in none of the 10 local governments learned to closely monitor performance (See Table C2 section (d) and Table C3 section (d)) by using evidence of substandard operational performance to highlight gaps between existing organizational arrangements and those necessary to support high levels of cooperation among stakeholders.

CIOs related how department managers left the IT group to account to top managers for process performance, even when the performance was affected by the department's poor use of enterprise systems. Top management failed, therefore, to disconfirm department managers' old cognitive frameworks. This finding was further evidenced by the document evidence that department managers still shared the old vision to reduce operational costs rather than innovate (i.e., poor sensitivity to operations) and CIO evidence that they reprogrammed rather than adopt the integrated organizational processes embedded in the enterprise systems (i.e., poor complexity seeking). Hence, seven local governments failed to adopt required IT structure and enact integrated enterprise systems use, and three local governments implemented enterprise systems, but they ignored the necessary change management to enact integrated use of the technology.

\subsection{Empirically derived theory: Know-how to lead digital transformation}

Our findings provide the empirical basis for a theory of the know-how for managers to lead digital transformation as follows: 
Enacting an integrated enterprise system to lead digital transformation requires local government managers to possess the know-how to exploit trigger events for discontinuous organizational change by concurrently (1) promulgating an analyzer type organizational strategy entwined with an innovation type IT strategy; and (2) using the integrated core organizational processes embedded in enterprise systems; and (3) restructuring the organization around those integrated organizational processes; and (4) restructuring IT governance with mindful best practices.

\section{How to transfer the requisite know-how? Implications and recommendations}

Having deduced what know-how local government managers require in the preceding section, we are now informed to embark on an inductive discussion of how to acquire that know-how and propose specific recommendations. Digital transformation literature recommends that organizations transfer-in the requisite know-how from external sources because reliance on internal learning-by-doing would increase rework, waste money, introduce security risks (Westerman et al., 2014), slow progress, and increase risk of failure (Hess et al., 2016). Empirical studies have pointed in broad terms to the need for social capital (Li, Su, Zhang, \& Mao, 2018), motivation (Hess et al., 2016), and relevant prior knowledge ('absorptive capacity', Klievink \& Janssen, 2009; Leonhardt, Haffke, Kranz, \& Benlian, 2017) to promote the transferin of external know-how for digital transformation. None of the studies, however, has sufficiently elaborated how these conditions enable the transfer of external know-how, and the conditions have not been integrated. In order to inform external know-how acquisition strategies, the following inductive discussion draws on extant literature and our empirical data to integrate and elaborate how certain conditions enable external know-how to be transferred in. This focus is important because external know-how is 'sticky' (i.e., difficult to transfer) since, unlike codified knowledge that can be readily stored in files for transfer to anyone, know-how loses meaning when codified (Montazemi et al., 2012). Under specific conditions, however, knowhow can be effectively transferred person-to-person while exploring the shared external IT 
environment.

Behaviors such as search, discovery, and innovation are central to exploratory learning (Fang, Lee, \& Schilling, 2010). Organizations that actively explore the external IT environment are more likely to learn about effective ways to implement and enact IT because higher performing firms know about more rewarding opportunities (Haunschild \& Miner, 1997). However, while exploration is necessary, it is not sufficient to act effectively on that know-how: local governments must exploit the IT in improved processes (Montazemi et al., 2012). Exploitation embodies behaviors such as implementation, refinement, and execution. Without exploitation, organizations will not realize the full benefits of exploration. Local government managers should explore the external IT environment with partners - including (1) IT service providers, (2) governments, and (3) universities - in order to transfer-in the requisite know-how for digital transformation (Westerman et al., 2014).

\subsection{Private-sector know-how to manage digital transformation}

CIOs in each case explained the limitations of selecting an integrated enterprise system from one private-sector IT service provider or another, as articulated by the Gamma CIO:

\footnotetext{
"If you were to look at how closely our financial system would align with one enterprise system - not very well. Another system is actually superior when it comes to financial processes, but the former enterprise system better represented our human resource management requirements. I'll tell you another one. The portal is not really customized for municipal government. Service providers really have to start from scratch to retrofit it."
}

This evidence suggests that IT service providers often fail to incorporate essential municipal organizational processes into enterprise systems. This oversight leads to technologies that fail to support important process goals for local governments. The root problem can be traced to knowhow transfer barriers in public-private collaboration. Evidence from our case studies shows that IT service providers in the private sector must acquire knowledge of the essential municipal 
organizational processes (i.e., organizational structure) (Bharadwaj, Saxena, \& Halemane, 2010), if they are to incorporate them into enterprise systems. Because it is tacitly embedded in the minds of managers, this process knowledge can only be acquired by IT service providers through a sophisticated process of knowledge transfer (Montazemi et al., 2012). The more complex the process to be incorporated into enterprise systems, the more difficult and complicated the knowledge transfer would be. To solve this problem, local government managers should establish knowledge sharing networks with private-sector IT service providers as follows.

We know that organizations learn from other organizations and industries how to understand and use technologies (Fang et al., 2010). Learning about complex technologies (such as integrated enterprise systems) requires formal structured networks of semi-autonomous partners with different core competencies. Government interest in the potential learning benefits of tapping into private-sector expertise is the drive behind public-private partnerships. Despite the interest, a recent review shows that few of these partnerships exhibit improved public service delivery (Roehrich, Lewis, \& George, 2014).

Two implications emerge from the foregoing literature. First, local governments should establish public-private partnerships with IT service providers in order to transfer context-relevant knowledge about the organizational processes of governance. Second, the shared cognitive framework that emerges in the social context of public-private partnerships can enhance local government managers' capacities to understand and enact IT-based innovations that emanate from IT service providers in the private sector. Local governments and private-sector partners could then co-create some of the requisite know-how to enact enterprise systems as an integrated system to support high levels of cooperation among stakeholders with process management (Delgado, Osella, Pastrone et al., 2016). 
A case in point is the SAP enterprise system to consolidate a vast number of legacy systems that Auckland city council approved for implementation in 2012 (O'Neill, 2015). However, because managers lacked the know-how to lead the implementation of integrated enterprise systems, the estimated 2012 budget of NZ\$71 million was revised to NZ\$157 million in 2014, and the implementation timeline increased by one year. A progress report identified root problems. First, it found that the council did not have the requisite IT strategy in place: the project steering committee had not agreed on what the project would deliver. Second, with regard to IT structure, governance roles and responsibilities were unclear, and an integrated project plan was missing.

To ameliorate the reported problems, city council decided to add a senior SAP executive to the city's IT steering group, and to include SAP architects in the team that lead implementation and enactment. With the public-private partnership in place, Auckland was on track to implement and enact integrated enterprise systems to transform public services (i.e., organizational structure). Based on the foregoing literature and evidence, we can advance our first recommendation:

Recommendation 1. Local governments and IT service providers should establish publicprivate partnerships with the purpose of (i) transferring context-relevant knowledge to IT service providers from local governments about their organizational processes; and (ii) cocreating some of the requisite know-how to enact an integrated enterprise system to support high levels of cooperation among stakeholders with process management.

Local government managers could also learn from their private sector counterparts. Managers in the private sector overcome a lack of know-how by outsourcing competence-based processes to IT service providers. These private-sector firms can deliver the processes better because they already have the necessary core competencies (Bharadwaj et al., 2010). Leveraging the technology ecosystem (Pittaway \& Autio, 2015) in this way could help local governments to innovate with IT. It would enable local government managers to focus on selecting the most rewarding innovations to improve public service delivery, and to choose the best plans for 
implementation (Irani \& Elliman, 2008). Based on the foregoing literature and evidence, we can advance a second recommendation:

Recommendation 2. Local government managers should outsource to IT service providers for their competencies in enacting integrated enterprise systems, and then focus on developing the core competence to manage selection of the most rewarding innovations and the best plans for implementing these innovations in support of improved public service delivery.

\subsection{Peers' know-how to manage digital transformation}

Local governments like Alpha have accumulated experience in successfully managing digital transformation. Because their know-how is more contextualized to fit the recipient's context requirements (Dennis \& Vessey, 2005; Gil-Garcia \& Sayogo, 2016; Pittaway, Qahri-Saremi, \& Montazemi, 2018), other local governments could acquire this know-how more efficiently than know-how emanating from IT service providers in the private sector. Peer local governments that exhibit above-average financial performance are especially good sources of know-how because they have experience with more rewarding opportunities on which the recipient can capitalize (Angst, Agarwal, Sambamurthy, \& Kelley, 2010). Prior research provides a framework for transfer of explicit procedural knowledge among public organizations (e.g., Cavalheiro \& Joia, 2014; Gil-Garcia \& Sayogo, 2016), but our focus here is on the under-researched transfer of tacit knowledge in the form of know-how. Earlier studies in the local government context provide no guidance on which factors confer on them the capacity to acquire and exploit know-how from peers, a so-called 'realized absorptive capacity' (Zahra \& George, 2002). However, the enabling factors are well researched in the context of multinational corporations (MNCs), which affords a potential conceptual model for local governments. To that end, a study by Montazemi et al. (2012) synthesized 31 empirical MNC studies to advance an integrated model for transferring know-how between peer subsidiaries. The MNC form of organization is conceptualized as an interorganizational network, comprised of a headquarters unit and geographically dispersed 
subsidiary units. We adapted this model to multi-tier governments by conceptualizing local governments akin to peer subsidiaries in an interorganizational network that are subject to higher-tier governments, akin to headquarters.

The core logic of the proposed model, depicted in Figure 3, is that the transfer of know-how between peers can be sticky. Stickiness pertains to the degree of perceived difficulty in knowhow transfer, which refers in turn to the extent of problems, such as communication difficulties, and unmet expectations. Three organizational factors enable (or in their absence, inhibit) the inter-organizational transfer of know-how: (1) social capital, which provides rich transmission channels and intrinsic incentives; (2) extrinsic incentives, which engender in peers the motivational dispositions to cooperate in transfer of know-how; and (3) the learning or potential 'absorptive' capacity of the recipient organization. By applying the proposed model (depicted in Figure 3 ) to the 11 cases we studied, important recommendations emerge for the local government context as follows.

Transfer of know-how is sticky unless the source and recipient have established social capital and motivational dispositions to cooperate in the transfer. Social capital is manifested through social interaction ties, a shared vision, and a collectively held trust orientation towards other local governments. By embedding interaction ties in an ongoing social relationship, individuals are exposed to diverse sources of knowledge, which encourages them to rethink the systematic nature of existing practices, and to revisit the structure of those practices. In our cases, MISA, a professional association, facilitated the development of social ties between local governments by providing a forum for interaction between local government CIOs at meetings and conferences. Notwithstanding MISA's success in facilitating social interaction, however, CIOs noted that systematic transfer of know-how between local governments rarely emerged. The proposed 
model (Figure 3) suggests that the absence of shared vision, trust and extrinsic incentives could have been a barrier to know-how transfer in our cases for two reasons.

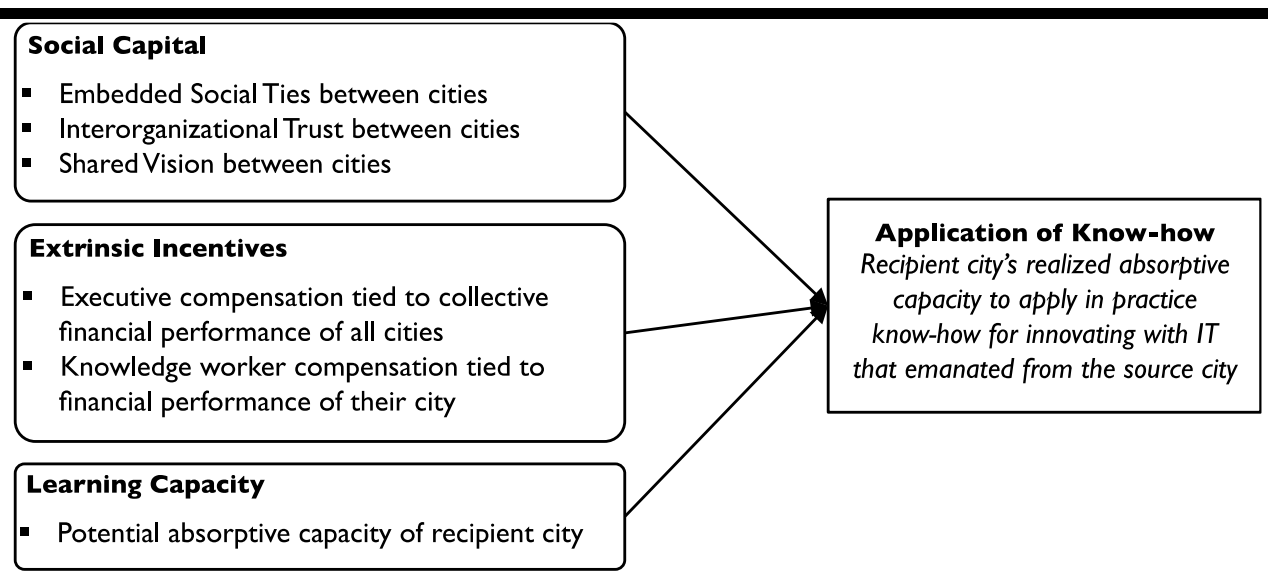

\section{Fig. 3. Proposed model of peer-to-peer transfer of know-how to local governments}

First, local governments that painstakingly deconstructed and reconstructed the requisite knowhow to lead the implementation and enactment of integrated enterprise systems (such as Alpha) would have a natural reluctance to share this know-how for fear of losing ownership, a position of privilege or superiority, and inadequate rewards for sharing their hard-won success (Montazemi et al., 2012). Second, power struggles within local government can lead some managers to try to undermine the potential power of other local governments by pretending that the knowledge they possess is not unique and valuable. Such myopia undermines the willingness to seek out and act on know-how, such as IT governance 'best practices', proffered by another local government. A shared vision, trust and extrinsic incentives can counteract these barriers.

A shared vision provides a common mindset on which to build a constructive rather than unproductive, conflict-ridden dialog in support of know-how transfer (Montazemi et al., 2012, e.g., Gil-Garcia \& Sayogo, 2016). A trusting orientation toward another unit can promote individuals' intrinsic motivational dispositions to cooperate in support of transfer, as 
psychological contracts based on emotional loyalties are established (Montazemi et al., 2012).

Extrinsic incentives also engender the motivational dispositions to share and to receive knowhow. For example, tying the compensation of top managers to collective performance goals provides them with an extrinsic incentive to share their know-how with others, because it will lead to better collective performance, and increase their own performance-based rewards. In addition, tying managers' compensation to their own organization's performance can engender a motivational disposition to acquire and act on know-how from other local governments in order to enhance the performance of their own organization. In the MNC context, headquarters actively (1) promotes extrinsic incentive schemes for knowledge sharing; (2) promulgates a shared vision for the collective; and (3) builds formal structures, processes, and routines for knowledge exchange between business units that creates a stable context within which interorganizational trust can develop and persist. Similar to MNC headquarters, higher tier national and provincial governments in our empirical context transfer payments to local governments to locally implement specific overarching policies (e.g., education, healthcare). It is conceivable that the higher tier governments could include policies for digitally integrated government across the traditional boundaries of public service delivery as part of the local government solution. However, the higher-tier governments, which could have acted like MNC headquarters, did not apply these tactics, and systematic transfer of know-how among local governments failed to emerge. Extant literature suggests that shared vision for solving a common problem, as well as mutual trust and motivation to share and enact new solutions, develop over time through joint problem-solving teams (Cavalheiro \& Joia, 2014; McEvily \& Marcus, 2005). These arguments are consistent with research in the government context that calls for collaborative dialogues through partnerships within government, between governments, and 
across sectors to achieve digitally enabled transformation (e.g., Allen, Juillet, Paquet, \& Roy, 2001; Visser \& Van der Togt, 2016). Based on the foregoing literature and findings, we can advance the following two recommendations:

Recommendation 3. Key stakeholders in public-service delivery, such as policymakers in higher-tier governments, local governments' chief administrative officers, and the citizens and businesses served, should demand that managers of multiple local governments actively work in joint problem-solving teams to identify opportunities to exploit private-sector knowhow to manage digital transformation.

Recommendation 4. Policymakers in higher-tier governments should exercise their authority to promote performance evaluation and incentive pay schemes for local governments that are explicitly linked to exploring for and exploiting private-sector know-how to manage digital transformation.

\subsection{Universities and learning capacity}

Transfer of know-how is sticky because its meaning is closely tied to the context in which it was first created (Montazemi et al., 2012). To apply received know-how in practice, it must be 'contextualized' to fit the recipient's context. This entails deconstructing the know-how, putting it into a general form (e.g., documents, frameworks, communications), and then reconstructing it in the recipient's context. However, the recipient managers may be unable to reconstruct the external know-how due to a lack of learning capacity, a so-called 'potential absorptive capacity' (Zahra \& George, 2002). Such capacity is a function, in part, of the recipient organization's preexisting stock of relevant knowledge (Cohen \& Levinthal, 1990; Zahra \& George, 2002). A key problem was that none of our 11 local governments at $t_{1}$ had a pre-existing stock of knowledge related to integrated enterprise systems implementation, so they had little learning capacity.

Consistent with the proposed model depicted in Figure 3, our case studies showed it was investments in education to enhance their learning capacity that conferred on Alpha an enhanced capacity to exploit internal triggers for change and manage digital transformation. Yet, despite the evident benefits that local governments gain from education, local educational institutions 
such as universities are a neglected resource (Hambleton, 2014).

Managers can engage universities in a significant role in digital transformation through the cocreation of new knowledge from research, policy and practice to transfer through education (Hambleton, 2014; Schenk \& Dolata, 2020). The knowledge co-creation process involves managers working together with researchers in real-world case studies, as well as action research, that develops a stock of knowledge relevant to policy and practice in the local government context. Insights drawn from this knowledge co-creation process can be integrated into education programs for managers. In this way, universities can become a key source for the stocks of relevant knowledge that confer on local governments an enhanced capacity to learn how to manage digital transformation. Therefore, based on the foregoing literature and findings, we can advance two final recommendations:

Recommendation 5. Local governments should work with academic institutions to develop an integrated knowledge base specific to the local government context, supplemented with additional in-depth case studies examining municipal governance that leverages privatesector know-how to manage digital transformation.

Recommendation 6. Local governments should work with academic institutions to design executive education programs specifically to close the knowledge gaps identified in this research.

Taken together, the foregoing recommendations point to the need for coordination across organizational and industry boundaries. As the effects of governance decisions in one organization influence those of their partners, questions arise regarding the optimality of coordinated decision making across organizational and industry boundaries (Lavie, Haunschild, \& Khanna, 2012). However, we know relatively little about mechanisms for governing these relationships effectively (Tihanyi, Graffin, \& George, 2014). Our proposed model, depicted in Figure 3, and recommendations advanced in this study can contribute to dialogue and practice on effective governance for public-private partnerships that support digital transformation. 


\section{Conclusions}

This article informs leadership of digital transformation in local governments. Our evidence shows that management requires the know-how to exploit trigger events for discontinuous organizational change by concurrently (1) promulgating an analyzer type organizational strategy entwined with an innovation type IT strategy; and (2) enacting the integrated core organizational processes embedded in enterprise systems; and (3) restructuring the organization around those integrated organizational processes; and (4) restructuring IT governance. Restructuring IT governance involves vesting IT investment power in the CIO; creating a collaborative IT group led by management; collaboratively monitoring gaps in performance to focus on achieving high levels of cooperation among stakeholders; and promulgating a shared innovation vision among departments. Managers should therefore exploit trigger events to promote rapid and concurrent organizational change in four dimensions - organizational strategy, IT strategy, organizational structure, and IT structure - if local governments are to realize the full potential of achieving digital transformation.

In terms of scholarship, prior literature on organizational capacity examined independent effects of know-how on financial outcomes (e.g., Carter, 2015). Our findings contribute to the literature by elaborating the configurational effects of know-how on leading digital transformation. In order to examine this phenomenon, we isolated the effects of heterogeneous know-how configurations between local governments by controlling for exogenous factors. Future research could relax this constraint in other jurisdictions to hypothesize the interaction effects of different types of external trigger events, and thereby inform additional interventions to further digital transformation. Extant theory and data from 11 case studies also contribute to our understanding of barriers that local government managers face in acquiring the requisite know-how, which 
relate to the absence of learning capacity, shared vision, interorganizational trust, and incentive schemes. We find that transfer of relevant knowledge to managers is the cornerstone for realizing the kinds of improved public services made possible by digital transformation. This study contributes a dynamic model of digital transformation, a theory of the requisite know-how to lead digital transformation, a model of how to transfer-in that know-how, and six recommendations to help realize this objective.

\section{Acknowledgement}

Research and preparation of the article was funded in part by Platform Value Now and Imperial College London's Digital City Exchange (EPSRC grant EP/I038837/1).

\section{References}

Allen, B. A., Juillet, L., Paquet, G., \& Roy, J. (2001). E-Governance \& government on-line in Canada: Partnerships, people \& prospects. Government Information Quarterly, 18(2), 93-104.

Angst, C. M., Agarwal, R., Sambamurthy, V., \& Kelley, K. (2010). Social contagion and information technology diffusion: The adoption of electronic medical records in US hospitals. Management Science, 56(8), 1219-1241.

Azad, B., \& Faraj, S. (2008). Making e-government systems workable: exploring the evolution of frames. Journal of Strategic Information Systems, 17(2), 75-98.

Bannister, F., \& Connolly, R. (2015). The great theory hunt: Does e-government really have a problem? Government Information Quarterly, 32(1), 1-11.

Bharadwaj, S. S., Saxena, K. B. C., \& Halemane, M. D. (2010). Building a successful relationship in business process outsourcing: an exploratory study. European Journal of Information Systems, 19(2), 168-180.

Brown, M. M. (2007). Understanding e-government benefits: An examination of leading-edge local governments. American Review of Public Administration, 37(2), 178-197.

Carter, L. (2015). Towards a "balanced" historical assessment of e-government research. in Electronic Government and Electronic Participation, Amsterdam, Netherlands.

Cavalheiro, G. M. d. C., \& Joia, L. A. (2014). Towards a heuristic frame for transferring e-government technology. Government Information Quarterly, 31(1), 195-207.

Chanias, S., Myers, M. D., \& Hess, T. (2019). Digital transformation strategy making in pre-digital organizations. Journal of Strategic Information Systems, 28(1), 17-33.

Chourabi, H., Nam, T., Walker, S., Gil-Garcia, J. R., Mellouli, S., Nahon, K., et al. (2012). Understanding smart cities: An integrative framework. in Proceedings of Hawaii International Conference on System Science, Hawaii, USA.

Cohen, W. M., \& Levinthal, D. A. (1990). Absorptive capacity: a new perspective on learning and innovation. Administrative Science Quarterly, 35(1), 128-152.

Cordella, A., \& Iannacci, F. (2010). Information systems in the public sector: the e-government enactment framework. Journal of Strategic Information Systems, 19(1), 52-66.

Delgado, M. T., Osella, M., Pastrone, C., Spirito, M., Tringale, A., Vermesan, O., et al. (2016). Value Cocreation Mechanisms. European Commission H2020 - UNIFY-IoT Project.

Dennis, A. R., \& Vessey, I. (2005). Three knowledge management strategies: Knowledge hierarchies, knowledge markets, and knowledge communities. MIS Quarterly Executive, 4(4), 399-412.

Devadoss, P. R., Pan, S. L., \& Huang, J. C. (2002). Structurational analysis of e-government initiatives: a case 
study of SCO. Decision Support Systems, 34(3), 253-269.

Eisenhardt, K. M. (1989). Making fast strategic decisions in high-velocity environments. Academy of Management Journal, 32(3), 543-576.

Elnaghi, M., Alshawi, S., \& Missi, F. (2007). A leadership model for e-government transformation. in Proceedings of European and Mediterranean Conference on Information Systems, Valencia, Spain.

Fang, C., Lee, J., \& Schilling, M. A. (2010). Balancing exploration and exploitation through structural design: the isolation of subgroups and organizational learning. Organization Science, 21(3), 625-642.

Fitzgerald, M., Kruschwitz, N., Bonnet, D., \& Welch, M. (2013). Embracing digital technology: a new strategic imperative. MIT Sloan Management Review, 55(2), 1-13.

Fountain, J. (2019). The wicked nature of digital transformation: a policy perspective. Dubai Policy Review, January(1).

Furneaux, B., \& Wade, M. (2011). An exploration of organizational level information systems discontinuance intentions. MIS Quarterly, 35(3), 573-598.

Gersick, C. J. (1991). Revolutionary change theories: a multilevel exploration of the punctuated equilibrium paradigm. Academy of Management Review, 16(1), 10-36.

Gil-Garcia, J. R. (2012). Towards a smart state? Inter-agency collaboration, information integration, and beyond. Information Polity, 17(3, 4), 269-280.

Gil-Garcia, J. R., Chengalur-Smith, I., \& Duchessi, P. (2007). Collaborative e-Government: impediments and benefits of information-sharing projects in the public sector. European Journal of Information Systems, 16(2), 121-133.

Gil-Garcia, J. R., \& Sayogo, D. S. (2016). Government inter-organizational information sharing initiatives: Understanding the main determinants of success. Government Information Quarterly, 33(3), 572-582.

Gil-Garcia, J. R., Zhang, J., \& Puron-Cid, G. (2016). Conceptualizing smartness in government: An integrative and multi-dimensional view. Government Information Quarterly, 33(3), 524-534.

Guba, E. G., \& Lincoln, Y. S. (1989). Fourth Generation Evaluation. Newbury Park, CA: Sage Publications.

Guevara, J., Stegman, E., \& Hall, L. (2012). IT Key Metrics Data: 2012 IT Enterprise Summary Report. Stamford, Connecticut: Gartner.

Guillemette, M. G., \& Paré, G. (2012). Toward a new theory of the contribution of the IT function in organizations. MIS Quarterly, 36(2), 529-551.

Hambleton, R. (2014). From the smart city to the wise city: the role of universities in place-based leadership. in Smart City: New Media, Social Participation and Urban Governance, Shanghai, China.

Hanna, N. K. (2010). Transforming Government and Building the Information Society: Innovation, Technology, and Knowledge Management. New York, NY: Springer.

Hansen, A. M., Kraemmergaard, P., \& Mathiassen, L. (2011). Rapid adaptation in digital transformation: a participatory process for engaging IS and business leaders. MIS Quarterly Executive, 10(4), 175-185.

Haunschild, P. R., \& Miner, A. S. (1997). Modes of interorganizational imitation: The effects of outcome salience and uncertainty. Administrative Science Quarterly, 42(3), 472-500.

Hess, T., Matt, C., Benlian, A., \& Wiesböck, F. (2016). Options for formulating a digital transformation strategy. MIS Quarterly Executive, 15(2).

Hirschheim, R., \& Sabherwal, R. (2001). Detours in the path toward strategic information systems alignment. California Management Review, 44(1), 87-108.

Hoberg, P., Krcmar, H., Oswald, G., \& Welz, B. (2015). Skills for Digital Transformation. Garching, DE: IDT.

Hofmann, S., \& Ogonek, N. (2018). Different but still the same? How public and private sector organisations deal with new digital competences. Electronic Journal of e-Government, 16(2), 127-135.

Huberman, M., \& Miles, M. B. (2002). The Qualitative Researcher's Companion. Thousand Oaks, CA: Sage Publications.

Iannacci, F., Seepma, A. P., de Blok, C., \& Resca, A. (2019). Reappraising maturity models in e-government research: the trajectory-turning point theory. Journal of Strategic Information Systems, 28(1), 310-329.

Irani, Z., \& Elliman, T. (2008). Creating social entrepreneurship in local government. European Journal of Information Systems, 17(4), 336-342.

ITGIOGC. (2005). Aligning COBIT®, ITIL® and ISO 17799 for Business Benefit: Management Summary.

Rolling Meadows, IL: IT Governance Institute and the Office of Government Commerce.

Janowski, T. (2015). Digital government evolution: from transformation to contextualization. Government 
Information Quarterly, 32(3).

Jones, B. D., \& Baumgartner, F. R. (2012). From there to here: Punctuated equilibrium to the general punctuation thesis to a theory of government information processing. Policy Studies Journal, 40(1), 1-20.

Kamal, M., Weerakkody, V., \& Irani, Z. (2011). Analyzing the role of stakeholders in the adoption of technology integration solutions in UK local government: An exploratory study. Government Information Quarterly, 28(2), 200-210.

Kim, H. J., Pan, G., \& Pan, S. L. (2007). Managing IT-enabled transformation in the public sector: A case study on e-government in South Korea. Government Information Quarterly, 24(2), 338-352.

Kitchin, R. (2015). Making sense of smart cities: addressing present shortcomings. Cambridge Journal of Regions, Economy and Society, 8(1), 131-136.

Klievink, B., \& Janssen, M. (2009). Realizing joined-up government: Dynamic capabilities and stage models for transformation. Government Information Quarterly, 26(2), 275-284.

Kohli, R., \& Johnson, S. (2011). Digital transformation in latecomer industries. MIS Quarterly Executive, $10(4)$.

Kumar, V., Maheshwari, B., \& Kumar, U. (2002). ERP systems implementation: Best practices in Canadian government organizations. Government Information Quarterly, 19(2), 147-172.

Landis, J. R., \& Koch, G. G. (1977). The measurement of observer agreement for categorical data. Biometrics, 33(1), 159-174.

Lavie, D., Haunschild, P. R., \& Khanna, P. (2012). Organizational differences, relational mechanisms, and alliance performance. Strategic Management Journal, 33(13), 1453-1479.

Leonhardt, D., Haffke, I., Kranz, J., \& Benlian, A. (2017). Reinventing the IT function: the role of IT agility and IT ambidexterity in supporting digital business transformation. in Proceedings of European Conference on Information Systems, Guimarães, Portugal.

Li, L., Su, F., Zhang, W., \& Mao, J. Y. (2018). Digital transformation by SME entrepreneurs: A capability perspective. Information Systems Journal, 28(6), 1129-1157.

Luna-Reyes, L. F., \& Gil-Garcia, J. R. (2014). Digital government transformation and internet portals: The coevolution of technology, organizations, and institutions. Government information quarterly, 31(4), 545555.

Lyytinen, K., \& Newman, M. (2008). Explaining information systems change: a punctuated socio-technical change model. European Journal of Information Systems, 17(6), 589-613.

MAH. (2010). Municipal Performance Measurement Program, Summary of 2008 Results. Ontario, Canada: Ministry of Municipal Affairs and Housing.

Mahmood, M. (2016). Enhancing citizens' trust and confidence in government through digital transformation. International Journal of Electronic Government Research, 12(1), 99-110.

Manville, C., Cochrane, G., Cave, J., Millard, J., Pederson, J. K., Thaarup, R. K., et al. (2014). Mapping Smart Cities in the EU. Brussels: European Union.

Mathis, S. (2014). The rise and fall and eventual rise again of the 'smart city': CityLab.

Matt, C., Hess, T., \& Benlian, A. (2015). Digital transformation strategies. Business \& Information Systems Engineering, 57(5), 339-343.

McDonald, M., \& Westphal, J. (2003). Getting by with the advice of their friends: CEOs' advice networks and firms' strategic responses to poor performance. Administrative Science Quarterly, 48(1), 1-32.

McEvily, B., \& Marcus, A. (2005). Embedded ties and the acquisition of competitive capabilities. Strategic Management Journal, 26(11), 1033-1055.

McKinsey. (2018). Delivering for Citizens, McKinsey Center for Government.

Mergel, I., Edelmann, N., \& Haug, N. (2019). Defining digital transformation: Results from expert interviews. Government Information Quarterly, 36(4), 101385.

Montazemi, A. R., Pittaway, J. J., \& Qahri-Saremi, H. (2010). Significance of IT governance in transformational government. in Transformational Government ( $t G O V$ ), London, UK

Montazemi, A. R., Pittaway, J. J., Qahri-Saremi, H., \& Wei, Y. (2012). Factors of stickiness in transfers of know-how between MNC units. Journal of Strategic Information Systems, 21(1), 31-57.

Moon, M. J., \& Norris, D. F. (2005). Does managerial orientation matter? The adoption of reinventing government and e-government at the municipal level. Information Systems Journal, 15(1), 43-60.

Nath, A. (2012). Streamlining the management and governance of e-government processes. in Proceedings of 
the Allied Academies International Conference, Las Vegas, Nevada.

Niehaves, B., Plattfaut, R., \& Becker, J. (2013). Business process management capabilities in local governments: A multi-method study. Government Information Quarterly, 30(3), 217-225.

O'Neill, R. (2015). 'Supercity' IT spending revealed, SAP the big winner. ZDNet, May 26.

Oborn, E., Barrett, M., \& Davidson, E. (2011). Unity in diversity: Electronic patient record use in multidisciplinary practice. Information Systems Research, 22(3), 547-564.

Omar, A., Weerakkody, V., \& Millard, J. (2016). Digital-enabled service transformation in public sector. in Proceedings of the 9th International Conference on Theory and Practice of Electronic Governance, Montevideo, Uruguay.

Orlikowski, W. J. (2000). Using technology and constituting structures: A practice lens for studying technology in organizations. Organization Science, 11(4), 404-428.

Pardo, T. A., Cresswell, A. M., Thompson, F., \& Zhang, J. (2006). Knowledge sharing in cross-boundary information system development in the public sector. Information Technology and Management, 7(4), 293-313.

Pederson, K. (2016). e-Government in local government: challenges and capabilities. Electronic Journal of Egovernment, 14(1), 99.

Phang, C. W., Kankanhalli, A., \& Ang, C. (2008). Investigating organizational learning in eGovernment projects: A multi-theoretic approach. Journal of Strategic Information Systems, 17(2), 99-123.

Pittaway, J. J., \& Autio, E. (2015). Toward strategies for capturing latent value in ecosystems. in Strategic Management Society Annual Conference, Denver, CO

Pittaway, J. J., \& Montazemi, A. R. (2018). Seeking the 'smart' in cities: managing the process of innovating with IT. in Americas Conference on Information Systems, New Orleans, USA.

Pittaway, J. J., Qahri-Saremi, H., \& Montazemi, A. R. (2018). Motivating CIO advice networking to improve firm performance. in Proceedings of the Hawaii International Conference on System Sciences, Hawaii, USA.

Plotnick, L., Turoff, M., \& Van Den Eede, G. (2009). Reexamining threat rigidity: implications for design. in Proceedings of the Hawaii International Conference on System Sciences, Hawaii, USA.

Roehrich, J. K., Lewis, M. A., \& George, G. (2014). Are public-private partnerships a healthy option? A systematic literature review. Social Science \& Medicine, 113(1), 110-119.

Ross, J. W. (2003). Creating a strategic IT architecture competency: Learning in stages. MIT Sloan CISR, 335(1), 3-15.

Sá, F., Rocha, Á., \& Cota, M. P. (2016). From the quality of traditional services to the quality of local eGovernment online services: A literature review. Government Information Quarterly, 33(1), 149-160.

Sabherwal, R., Hirschheim, R., \& Goles, T. (2001). The dynamics of alignment: insights from a punctuated equilibrium model. Organization Science, 12(2), 179-197.

Schenk, B., \& Dolata, M. (2020). Facilitating digital transformation through education: a case study in the public administration. in Proceedings of the Hawaii International Conference on System Sciences, Hawaii, USA.

Sharma, R., \& Yetton, P. (2007). The contingent effects of training, technical complexity, and task interdependence on successful information systems implementation. MIS Quarterly, 31(2), 219-238.

Silva, L., \& Hirschheim, R. (2007). Fighting against windmills: strategic information systems and organizational deep structures. MIS Quarterly, 31(2), 327-354.

Tihanyi, L., Graffin, S., \& George, G. (2014). Rethinking governance in management research. Academy of Management Journal, 57(6), 1535-1543.

Tushman, M. L., Newman, W. H., \& Romanelli, E. (1986). Convergence and upheaval: managing the unsteady pace of organizational evolution. California Management Review, 29(1), 29-44.

Vial, G. (2019). Understanding digital transformation: A review and a research agenda. Journal of Strategic Information Systems.

Visser, M., \& Van der Togt, K. (2016). Learning in public sector organizations: A theory of action approach. Public Organization Review, 16(2), 235-249.

Walcroft, D., Chiasson, G., \& Murty, N. (2018). Creating the smart cities of the future. PwC: PwC.

Weerakkody, V., Irani, Z., Lee, H., Osman, I., \& Hindi, N. (2015). E-government implementation: A bird's eye view of issues relating to costs, opportunities, benefits and risks. Information Systems Frontiers, 
17(4), 889-915.

Weerakkody, V., Janssen, M., \& Dwivedi, Y. K. (2011). Transformational change and business process reengineering (BPR): lessons from the British and Dutch public sector. Government Information Quarterly, 28(3), 320-328.

Weerakkody, V., Omar, A., El-Haddadeh, R., \& Al-Busaidy, M. (2016). Digitally-enabled service transformation in the public sector: the lure of institutional pressure and strategic response towards change. Government Information Quarterly, 33(4), 658-668.

Weick, K. E., Sutcliffe, K. M., \& Obstfeld, D. (1999). Organizing for high reliability: processes of collective mindfulness. In R. S. Sutton \& B. M. Staw (Eds.), Research in Organizational Behavior (pp. 31-66). Stanford, CA: JAI Press.

Westerman, G., Bonnet, D., \& McAfee, A. (2014). Leading Digital: Turning Technology into Business Transformation. Boston, Massachusetts: Harvard Business Press.

Xue, Y., Liang, H., \& Boulton, W. R. (2008). Information technology governance in information technology investment decision processes: The impact of investment characteristics, external environment, and internal context. MIS Quarterly, 32(1), 67-96.

Yin, R. K. (2003). Case Study Research: Design and Methods. Thousand Oaks, CA: Sage Publications.

Zahra, S. A., \& George, G. (2002). Absorptive capacity: A review, reconceptualization, and extension. Academy of Management Review, 27(2), 185-203.

Zaizi. (2018a). Over half of government departments are not future-proofing their digital transformation projects. Open Access Government.

Zaizi. (2018b). Redesigning Government's Digital DNA: Government Survey Report 2018. London, UK.

\section{Appendix A - Further Rationale for Research Design}

Developing our conceptual framework (Figure 1) in advance of case studies: (1) helped us to ensure that we remained theoretically aware during our discussions; and (2) improved our ability to prompt informants concerning some potentially relevant issues for which informants had low salience or limited awareness at the time of our discussion (Furneaux \& Wade, 2011). Specifying semi-structured interview questions based on literature in advance of case study permitted data to be collected and analyzed in a consistent fashion, and substantiates the theoretical validity of qualitative study (Huberman \& Miles, 2002). We selected cases that would maximize similarities with respect to external influences, but maximize variation and allow comparisons with respect to dimensions of interest (Guba \& Lincoln, 1989). Similarities pertained to external triggers for discontinuous change, as depicted in Table 1, in order to naturally control external triggers in the public sector (Silva \& Hirschheim, 2007). Variation pertained to digital transformation progress. In order to enable cross-case comparisons, we added case studies until data gathering exhibited redundancy, at which point efforts to recruit additional cases cannot be justified in terms of the additional outlay of energy and resources (Guba \& Lincoln, 1989). In total, we examined 11 local governments. Multiple sources of evidence, in terms of semi-structured interviews and official documents, were used to triangulate findings where applicable. We coded data from interviews and official documents in a consistent fashion by using the coding rubric replicated in Table 1, which we synthesized from the literature referenced in Table 1. Two researchers independently coded qualitative data gathered from interviews, and documents, in order to enhance reliability (Eisenhardt, 1989). Inter-rater reliability demonstrated good agreement at $90.38 \%$ and Kappa of 0.864, which represents "almost perfect" strength of agreement (Landis \& Koch, 1977). Disagreements were resolved by discussion, and we proceeded only when we obtained unanimous agreement with respect to the coding. Finally, we sent a copy of our report to interviewees for review and comment, and their agreement substantiated the interpretive and evaluative validity of our findings (Huberman \& Miles, 2002). 


\section{Appendix B - Quantitative Comparative Case Data}

Table B1

Technology enactment: annual IT spend per employee

\begin{tabular}{|c|c|c|c|}
\hline Cases & IT Spend per Employe & nnual) & Cluster \\
\hline Mu local government & $\$$ & 1,033 & 2 \\
\hline Lambda local government & $\$$ & 2,717 & 2 \\
\hline Epsilon local government & $\$$ & 2,555 & 2 \\
\hline Kappa local government & $\$$ & 2,426 & 2 \\
\hline Zeta local government & $\$$ & 4,023 & 2 \\
\hline Beta local government & $\$$ & 5,213 & 2 \\
\hline Theta local government & $\$$ & 3,243 & 2 \\
\hline Gamma local government & $\$$ & 5,115 & 3 \\
\hline Delta local government & $\$$ & 4,943 & 3 \\
\hline Iota local government & $\$$ & 3,453 & 3 \\
\hline Alpha local government & $\$$ & 6,442 & 1 \\
\hline Benchmark: Banking and Financial Services & $\$$ & 24,128 & - \\
\hline Benchmark: Chemicals & $\$$ & 7,377 & - \\
\hline Benchmark: Construction, Materials and Natural Resources & $\$$ & 4,589 & - \\
\hline Benchmark: Consumer Products & $\$$ & 7,296 & - \\
\hline Benchmark: Education & $\$$ & 6,020 & - \\
\hline Benchmark: Energy & $\$$ & 13,449 & - \\
\hline Benchmark: Food and Beverage Processing & $\$$ & 5,299 & - \\
\hline Benchmark: Government -National/International & $\$$ & 17,811 & - \\
\hline Benchmark: Government -State/Local & $\$$ & 7,773 & - \\
\hline Benchmark: Healthcare Providers & $\$$ & 5,416 & - \\
\hline Benchmark: Industrial Electronics and Electrical Equipment & $\$$ & 8,258 & - \\
\hline Benchmark: Industrial Manufacturing & $\$$ & 5,676 & - \\
\hline Benchmark: Insurance & $\$$ & 28,390 & - \\
\hline Benchmark: Media and Entertainment & $\$$ & 14,130 & - \\
\hline Benchmark: Pharmaceuticals, Life Sciences and Medical Products & $\$$ & 9,633 & - \\
\hline Benchmark: Professional Services & $\$$ & 10,997 & - \\
\hline Benchmark: Retail and Wholesale & $\$$ & 4,733 & - \\
\hline Benchmark: Software & $\$$ & 17,860 & - \\
\hline Benchmark: Telecommunications & $\$$ & 16,072 & - \\
\hline Benchmark: Transportation & $\$$ & 7,063 & - \\
\hline Benchmark: Utilities & $\$$ & 17,944 & - \\
\hline
\end{tabular}

Table B2

Technology enactment: Group statistics for IT spend per employee

\begin{tabular}{|c|r|r|r|r|}
\hline Cluster of & \multicolumn{1}{|c|}{ Mean } & Std. Deviation & Std. Error Mean \\
\hline benchmarks & 22 & 11482.818 & 6601.169 & 1407.374 \\
\hline 7 local governments & 7 & 3030.000 & 1321.194 & 499.365 \\
\hline 3 local governments & 3 & 4503.667 & 913.959 & 527.675 \\
\hline Alpha & 1 & 6442.000 &. &. \\
\hline
\end{tabular}

Table B3

Technology enactment: t-test for equality of cluster means in IT spend per employee

\begin{tabular}{|c|c|c|c|c|c|c|c|c|}
\hline Cluster comparison & $t$ & $\mathrm{df}$ & $\begin{array}{l}\text { Sig. ( } \\
\text { tailec }\end{array}$ & & $\begin{array}{c}\text { Mean } \\
\text { Difference }\end{array}$ & $\begin{array}{l}\text { Std. Error } \\
\text { Difference }\end{array}$ & Lower C.I. & $\begin{array}{l}\text { Upper } \\
\text { C.I. }\end{array}$ \\
\hline 7 local governments - benchmarks & -3.327 & 27 & 0.003 & * & -8452.818 & 2540.729 & -13665.964 & -3239.672 \\
\hline 3 local governments - benchmarks & -1.796 & 23 & 0.086 & & -6979.152 & 3885.623 & -15017.175 & 1058.872 \\
\hline Alpha - benchmarks & -0.747 & 21 & 0.463 & & -5040.818 & 6749.528 & -19077.230 & 8995.594 \\
\hline
\end{tabular}




\section{Appendix C - COBIT IT Governance Matrix Coding}

\section{Table C1}

Alpha: IT governance decision rights vs. COBIT (Source ITGIOGC, 2005)

\begin{tabular}{|c|c|c|c|c|}
\hline \multirow[b]{2}{*}{ Decisions: } & \multicolumn{4}{|c|}{ Which stakeholders have accountability for each decision? } \\
\hline & $\begin{array}{c}\text { Senior } \\
\text { Executives }\end{array}$ & $\begin{array}{c}\text { Department } \\
\text { Managers }\end{array}$ & $\begin{array}{c}\text { IT } \\
\text { Management }\end{array}$ & $\begin{array}{c}\text { Audit/ } \\
\text { Compliance }\end{array}$ \\
\hline \multirow{2}{*}{\multicolumn{5}{|c|}{$\begin{array}{l}\text { Strategy alignment } \\
\text { Optimum resource use }\end{array}$}} \\
\hline & & & & \\
\hline \multicolumn{5}{|l|}{ 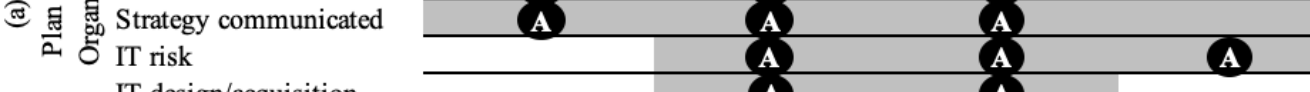 } \\
\hline & & & (A) & \\
\hline \multirow{2}{*}{\multicolumn{5}{|c|}{$\begin{array}{l}\text { New projects meet needs } \\
\text { On-time on-budget }\end{array}$}} \\
\hline & & & & \\
\hline \multicolumn{5}{|l|}{ 宣要 IS works properly } \\
\hline \multicolumn{5}{|l|}{ Minimize disruption } \\
\hline & & & & \\
\hline (.) Optimized IT costs & A & & & \\
\hline Productive integrated use & & & & \\
\hline & & (A) & & A \\
\hline (ิ) & & & (A) & \\
\hline$\Sigma=$ Independent assurance & (A) & & & (A) \\
\hline
\end{tabular}

Table C2

Cluster of three local governments: IT governance decision rights vs. COBIT (Source ITGIOGC, 2005)

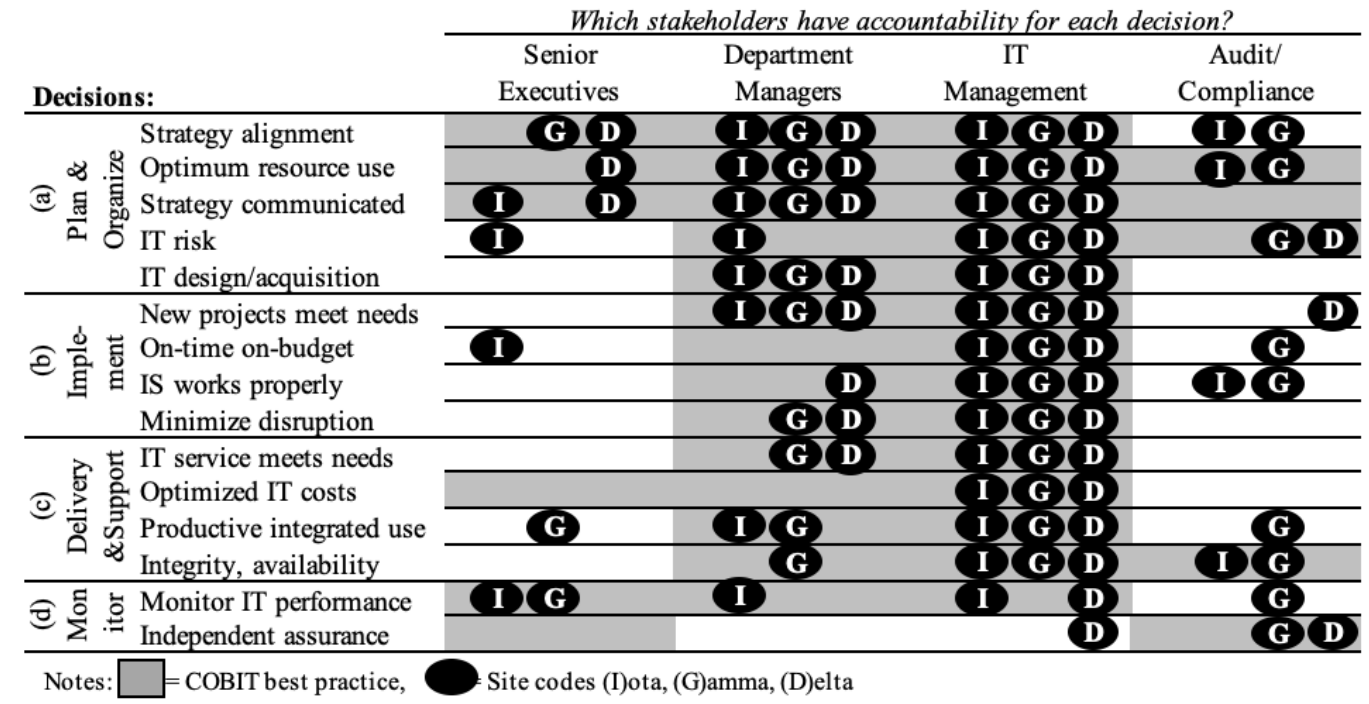


Table C3

Cluster of seven local governments: IT governance decision rights vs. COBIT (Source ITGIOGC, 2005)

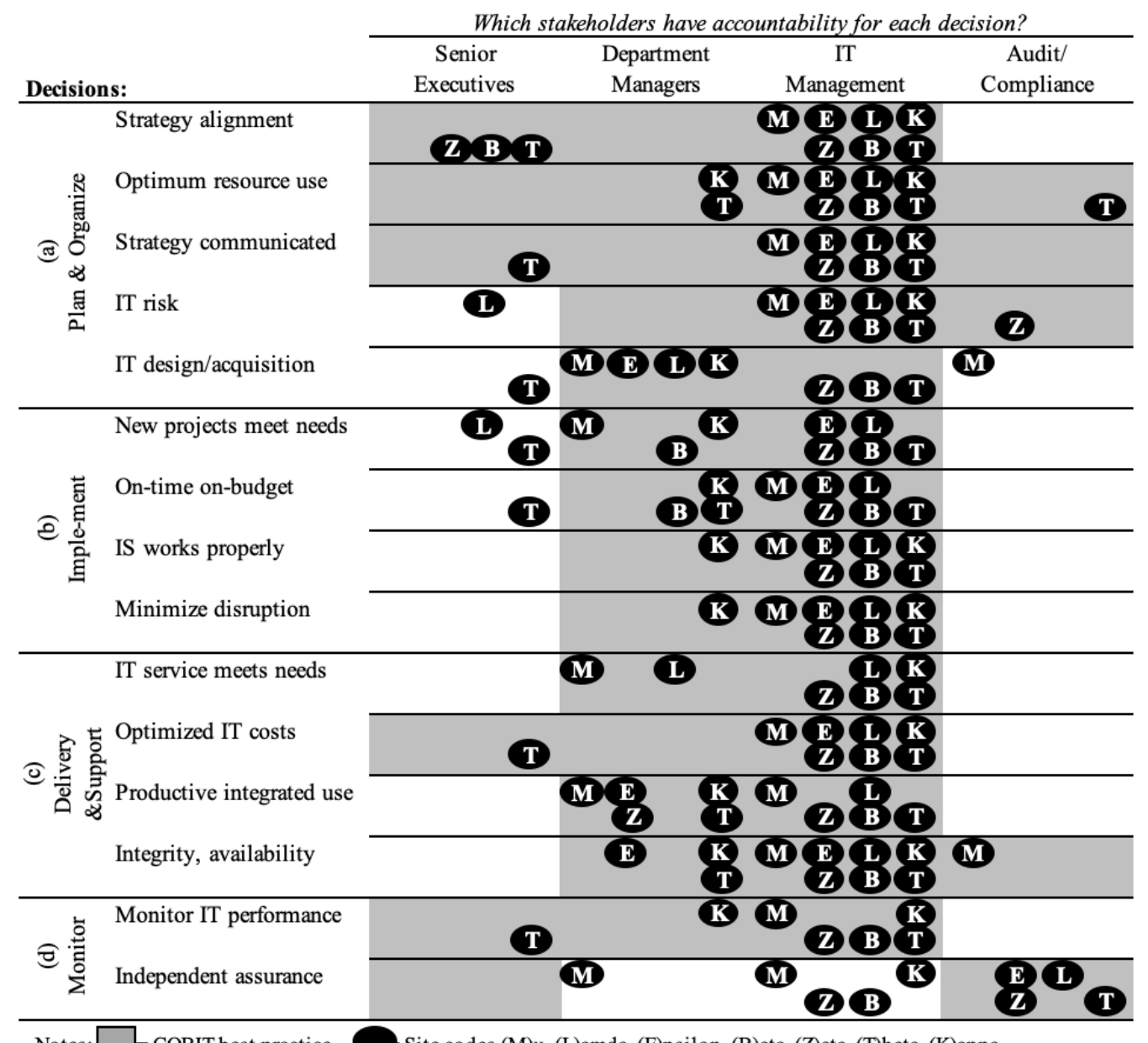

Notes: $\square=$ COBIT best practice, Site codes (M)u, (L)amda, (E)psilon, (B)eta, (Z)eta, (T)heta, (K)appa 